\title{
PENYULUHAN, PELATIHAN, DAN PERAGAAN PROSES PENGOLAHAN KENTANG MENJADI BERBAGAI PRODUK PANGAN KOMERSIL
}

\section{Rini $B^{1)^{*}}$, Fauzan Azima ${ }^{2)}$, Kesuma Sayuti ${ }^{3)}$, Novelina ${ }^{4)}$, Rina Yenrina ${ }^{5)}$, Novizar Nazir ${ }^{6)}$, Tuty Anggraini $^{7)}$, Hasbullah ${ }^{8)}$, Aisman $^{9)}$, Daimon Syukri ${ }^{10)}$, Diana Sylvi ${ }^{11)}$, Purnama Dini Hari $^{12)}$, Ismed ${ }^{13)}$, Cesar Welya Refdi ${ }^{14)}$, Wellyalina ${ }^{15)}$, Felga Zulfia Rasdiana ${ }^{16)}$, Reni Koja ${ }^{17)}$ \\ ${ }^{1)}$ Jurusan Teknologi Hasil Pertanian, Fakultas Teknologi Pertanian, Universitas Andalas, Kampus Limau Manis Padang-25163. email: rinibahar59@yahoo.com \\ ${ }^{2-17)}$ Jurusan Teknologi Hasil Pertanian, Fakultas Teknologi Pertanian, Universitas Andalas, Kampus Limau Manis Padang-25163}

\begin{abstract}
ABSTRAK
Kegiatan pengabdian masyarakat yang dilaksanakan oleh Jurusan Teknologi Hasil Pertanian Fakultas Teknologi Pertanian Universitas Andalas Padang ini bekerja sama dengan mitrayaitu Pondok Pesantren Dr M Natsir di Batu Bagiriak Alahan Panjang, Kabupaten Solok, Provinsi Sumatera Barat. Lokasi kegiatan pengabdian merupakan pondok pesantren yang mana di lingkungan sekitar kaya akan hasil pertanian dan perkebunan. Salah satu komoditi yang banyak dibudidayakan oleh masyarakat sekitaran pondok pesantren adalah kentang. Tanaman kentang ditanam masyarakat di pinggiran kebun atau di pekarangan rumah, tanaman ini tumbuh subur dan berproduksi cukup tinggi di daerah ini. Permasalahan yang dihadapi oleh mitra adalah 1) Umumnya kentang hanya dijual dalam bentuk mentah, pengolahan yang umum dilakukan masyarakat setempat hanya sekedar direbus atau digoreng saja dengan campuran dengan cabe merah, 2) Kurangnya pengetahuan anggota kelompok dalam aspek pengolahan berbagai macam produk olahan. Kegiatan yang telah dilaksanakan oleh tim pengabdian masyarakat untuk menyelesaikan permasalahan mitra adalah 1) Mengevaluasi kegiatan budidaya pertanian dan perkebunan yang ada dilokasi mitra, 2) Kegiatan penyuluhan pengolahan produk olahan dari kentanguntuk meningkatkan nilai jual produk dan ekonomi petani 3) Diversifikasi produk olahan dari kentang untuk meningkatkan umur simpan produk dengan pembuatan berbagai macam produk yaitu donat frozen, stik frozen, es krim, kulit kebab, dan minuman fungsional. Kegiatan ini berlangsung dengan baik dan lancar serta tingginya antusias peserta dalam mengikuti kegiatan ini terutama pada kegiatan pengolahan produk. Kegiatan ini diharapkan meningkatkan kualitas dan kuantitas produksi usaha mitra,dan peningkatan pendapatan mitra.
\end{abstract}

Kata Kunci: Batu Bagiriak Alahan Panjang, Pertanian, Kentang, Diversifikasi, Wirausaha

\section{PENDAHULUAN}

Alahan Panjang adalah salah satu Nagari

di Kabupaten Solok, Sumatera Barat,

Indonesia. Nagari yang beranjak sekitar 65

km dari Kota Padang ini berada diatas Bukit

Barisan tempatnya di lereng bagian timur

kawasan Taman Nasional Kerinci Seblat

pada ketinggian 1.400-1.600 mdpl. Nagari

Alahan Panjang terdiri dari 10 (sepuluh)

jorong, yaitu Alahan Panjang, Pangalian

Kayu, Galagah, Taluak Dalam, Taratak

Tangah, Batu Putiah, Taratak Galundi,
Batang Hari, Usak, Batu Bagiriak, Padang

Laweh, dan Sungai Nanam. Salah satu

daerah destinasi wisata andalan nagari alahan panjang adalah danau Kembar (Danau di Atas dan Danau di Bawah).

Alahan panjang termasuk salah satu daerah dataran tinggi di Sumatera Barat dengan curah hujan rata-rata 212 hari per tahun (BPS Solok, 2017). Dengan iklim yang sejuk dan curah hujan yang cukup tinggi membuat alahan panjang menjadi daerah yang subur untuk bercocok tanam. Hampir 
semua jenis tanaman dapat tumbuh dengan

baik di daerah ini. Daerah Solok khususnya Alahan Panjang menjadi salah satu pemasok hasil pertanian dan perkebunan terbaik di Sumatera Barat. Salah satu komoditi yang banyak dibudidayakan oleh masyarakat adalah kentang (Solanum tuberosum L).

Kentang (Solanum tuberosum L.) merupakan salah satu umbi-umbian yang banyak digunakan sebagai sumber karbohidrat atau makanan pokok bagi masyarakat dunia setelah gandum, jagung dan beras. Sebagai umbi-umbian, kentang cukup menonjol dalam kandungan zat gizinya. Perbandingan protein terhadap karbohidrat yang terdapat di dalam umbi kentang lebih tinggi dari pada biji serealia dan umbi lainnya. Kandungan asam amino umbi kentang juga seimbang sehingga sangat baik bagi kesehatan (Niederhauser 1993). Umbi kentang mengandung sedikit lemak dan kolesterol, namun mengandung karbohidrat, sodium, serat diet, protein, vitamin $\mathrm{C}$, kalsium, zat besi dan vitamin $\mathrm{B} 6$ yang cukup tinggi.

Pengenalan pengolahan makanan berbasis kentang kepada masyarakat di daerah ini, diharapkan dapat meransang munculnya masyarakat, anak pesantren Dr M Natsir, kelompok masyarakat, industri rumahan atau Usaha Mikro Kecil yang mengolah kentang menjadi produk olahan. Dengan demikian dapat meningkatkan nilai tambah dari kentang yang dihasilkan oleh masyarakat. Kegiatan ini sekaligus mempersiapkan masyarakat menyediakan makanan khas daerah berbasis kentang untuk berkembangnya daerah ini sebagai destinasi wisata di Sumatera Barat.

Kelompok sasaran yang dipilih dalam pengenalan pengolahan makanan berbasis kentang ini adalah Pondok Pesantren Dr M Natsir di Batu Bagiriak Alahan Panjang Kabupaten Solok. Pimpinan pondok adalah Darman. Selain itu, kelompok masyarakat sekitaran pondok juga ikut mengikuti kegiatan pengabdian ini. Pelatihan ini, setidaknya akan menjadi dasar mereka untuk berwirausaha dan juga merubah pola pikir untuk berpikir selangkah lebih jauh ke depan dan lebih mandiri.Aspek mutu yang perlu diperhatikan adalah jenis bahan baku, ketersediaan bahan baku, mutu atau kualitas bahan baku, nilai gizi bahan baku dan penyimpanan bahan baku. Aspek produksi diantaranya kontinyutas produksi, teknologi mesin dalam pembuatan produk dan sanitasi pengolahansehingga nilai produk bertambah tinggi.

Tujuan dari kegiatan pengabdian ini adalah meningkatkan pengetahuan, kemandirian dan keinginan berwirausaha bagi anggota pondok pesantren " $\mathrm{Dr} \mathrm{M}$ Natsir" dan masyarakat sekitar dengan cara aplikasi teknologi produksi pada pembuatan donat frozen, stik frozen, es krim, kulit kebab, dan minuman fungsional.

Pelatihan diberikan dengan metode pedagogi yang meliputi metode ceramah, demonstrasi pembuatan dan diskusi. Alat peraga yang disediakan berupa bahan mentah, peralatan dan mesin yang digunakan 
untuk pembuatan produk. Tim pengabdian masyarakat akan menentukan dan melibatkan peserta secara aktif dalam proses pengolahan produk. Terakhir dilakukan evaluasi terhadap ilmu yang sudah diperoleh.

Mitra pengabdian adalah Pondok Pesantren Dr M Natsir beserta kelompok Tani sekitaran pondok yang sedang menjalankan usaha pertanian budidaya dan penjualan tanaman labu kuning. Permasalahan yang dihadapi oleh mitra adalah masih rendahnya mutu produk yang dihasilkan oleh kelompok anggota pesantren maupun masyarakat sekitar "Dr M Natsir" karena minimnya pengetahuan anggota kelompok dalam berbagai olahan produk berbasis kentang. Pada bagian pengolahan pascapanen masih kurangnya pengetahuan mitra tentang pengolahan produk dari kentang, produk lebih banyak dijual dalam bentuk segar, pengolahan yang umum dilakukan masyarakat setempat hanya sekedar direbus atau digoreng saja yang dicampur dengan cabe merah, dan belum adanya diversifikasi produk olahan lain. Solusi yang ditawarkan oleh tim pengabdian masyarakat untuk menyelesaikan permasalahan mitra adalah penyuluhan terkait pemanfaatan produk pertanian kentang yang melimpah dengan harga murah dengan melalui pengolahan produk yang bernilai ekonomis. Pada tahapan pasca panen akan dilakukan diversifikasi produk olahan dari kentang.
METODE PELAKSANAAN KEGIATAN

\section{Penyuluhan}

Penyuluhan dilaksanakan sebagai proses awal untuk membangkitkan kemauan anggota kelompok pondok pesantren " $\mathrm{Dr} \mathrm{M}$ Natsir" dan masyarakat sekitar untuk menjadi mandiri dan mau berwirausaha. Dalam hal ini, mereka akan diberikan materi dan informasi-informasi mengenai pemanfaatan bahan baku lokal yang banyak terdapat dilingkungan menjadi produk-produk olahan yang lebih bernilai.

\section{Pelatihan}

Aplikasi teknologi dalam pembuatan donat frozen, stik, es krim, kulit kebab, dan minum fungsional dari kentang yang diajarkan secara langsung kepada para peserta melalui proses demonstrasi dan aplikasi langsung oleh para peserta.

\section{Bimbingan}

Kendala-kendala dalam proses pembuatan produk olahan berbasis kentang dalam memasarkan produknya tentu akan dijumpai di lapangan. Karena itu, setelah proses penyuluhan dan pelatihan dilangsungkan, untuk hari-hari selanjutnya diberikan bimbingan kepada peserta sehingga mampu memproduksi dan memasarkan produk dalam jumlah yang relatif lebih besar.

\section{HASIL DAN PEMBAHASAN}

Kegiatan pengabdian masyarakat ini diikuti 105 orang peserta yang terdiri dari anak pesantren, kelompok masyarakat, ibuibu pkk, wirausahawan baru, dosen, dan mahasiswa. Kegiatan ini dilaksanakan pada hari Minggu dan Senintanggal 28-29 Maret 
2021di Batu Bagiriak Alahan Panjang, kegiatan yaitu pembuatan produk donat Kabupaten Solok, Provinsi Sumatera Barat frozen, stik frozen, es krim, kulit kebab, dan dengan topikpengolahan pangan berbasis minuman fungsional. Kegiatan ini kentang .

Pada kegiatan pengabdian masyarakat ini di awali dengan kegiatan penyuluhan tentang teknologi pengolahan kentang oleh narasumber dari jurusan Teknologi Hasil Pertanian, Fakultas Teknologi Pertanian, Universitas Andalas Padang. Pada kegiatan penyuluhan ini narasumber menjelaskan tentang aspek-aspek dalam teknologi pengolahan kentang. Pengenalan tentang penanganan bahan baku sebelum diproses lebih lanjut menjadi produk merupakan topik awal yang disampaikan kepada peserta yang megikuti kegiatan ini. Menurut narasumber bahan baku dengan penanganan yang baik akan menghasilkan produk yang baik pula. Lebih lanjut narasumber menitikberatkan kepada kualitas dan kesegaran produk kentang, karena tanaman kentang ini mudah rusak disebabkan kadar air yang tinggi sehingga proses pengolahan harus segera dilakukan.

Topik kedua yang disampaikan dalam kegiatan penyuluhan adalah proses pengolahan produk kentang. Dalam proses pengolahan kentang dijelaskan jenis-jenis dan bentuk produk olahan yang dapat dihasilkan sebagai usaha baru seperti donat frozen, stik frozen, es krim, kulit kebab, dan minuman fungsional.

Kegiatan penyuluhan teknologi pengolahan kentang dilakukan pembuatan langsung produk olahan kentang oleh peserta didampingi langsung oleh dosen dan mahasiswa Jurusan Teknologi Hasil Pertanian.

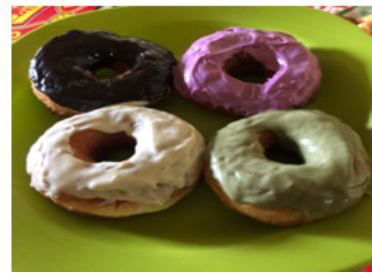

(a)

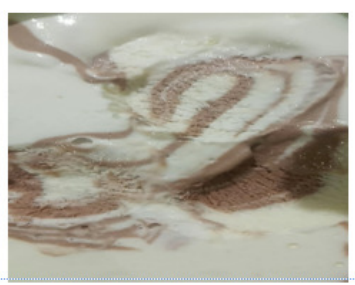

(c)

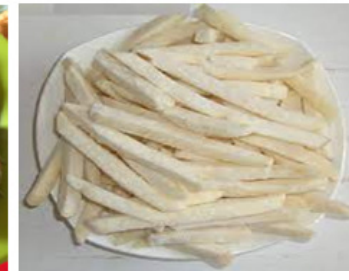

(b)

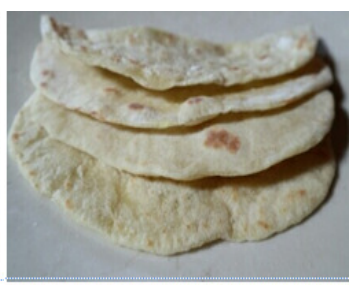

(d)

Gambar 1. Produk olahan kentang (a) Donat; (b) Stik; (c) Es krim; (d) Kulit kebab

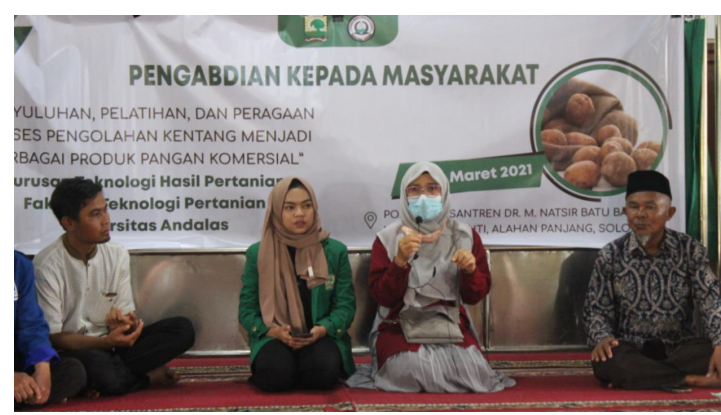

Gambar 2. Penyampaian materi teknologi pengolahan pangan berbasis kentang

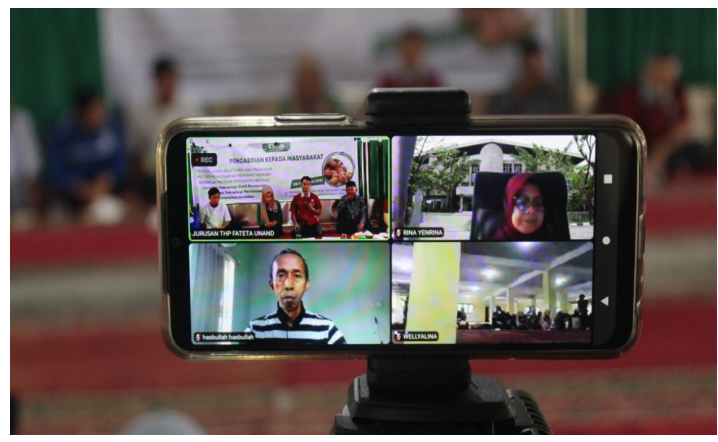

Gambar 3. Penyampaian materi kewirausahaan secara online dan offline 

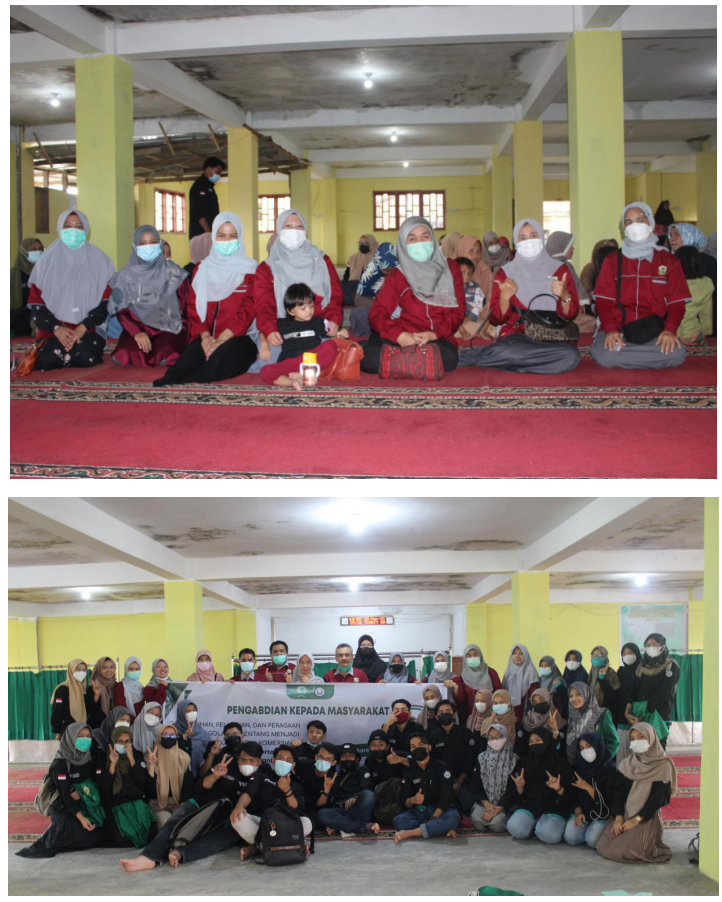

Gambar 4. Tim dan mitra pengabdian masyarakat

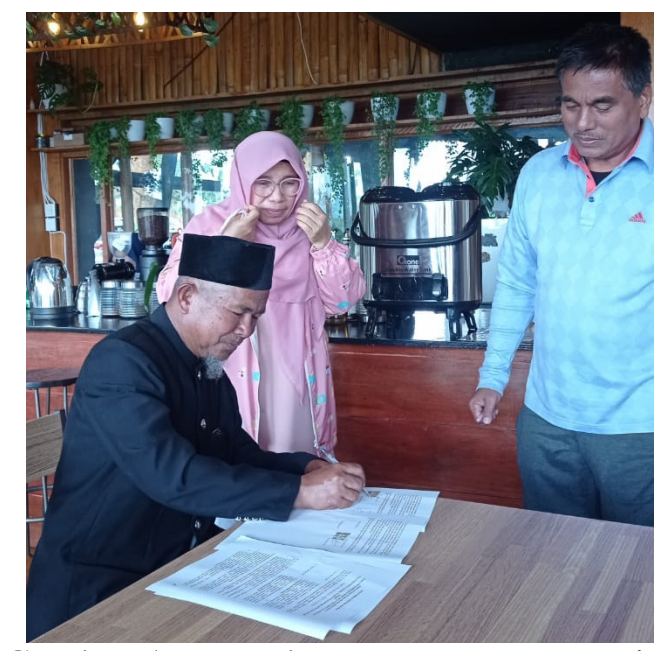

Gambar 5. Penandatangan MoU antara tim pengabdian masyarakat dengan mitra untuk keberlanjutan program

\section{KESIMPULAN}

Pada kegiatan pengabdian masyarakat ini telah dilakukan kegiatan penyuluhan, pelatihan dan pembuatan produk olahan dari kentang kepada mitra. Pengetahuan atau transfer ilmu pengetahuan tentang aspek teknologi, proses pengolahan, dan penyimpanan, produk olahan berbasis kentang telah diketahui dan dipahami oleh mitra. Kegiatan pengabdian masyarakat ini berjalan dengan baik lancar semoga bisa meningkatkan perekonomian masyarakat terutama yang bergerak dibidang budidaya pertanian dan perkebunan.

\section{SARAN}

Diharapkan kegiatan bisa dilakukan secara berkesinambungan dan pedampingan terutama adanya bantuan atau stimulasi peralatan penunjang sehingga bisa meningkatkan kualitas dan kuatitas produk olahan mitra.

\section{REFERENSI}

[1] Asgar, A. 2013. Umbi Kentang (Solanum tuberosum L.) Klon 395195.7 dan CIP 394613.32 yang Ditanam di Dataran Medium Mempunyai Harapan untuk Keripik. Balai Penelitian Tanaman Sayuran. Bandung.

[2] Badan Pusat Statistik Kabupaten Solok. 2017. Kecamatan Lembah Gumanti Dalam Angka 2017. CV Demy.

[3] Bug. 2005.Clavigralla tomentosicollis STAL (Heteroptera: Coreidae). Agricultura Tropica etSubtropica. VOL. 38(2).

[4] LPPM Unand. 2017. Panduan Penelitian dan Pengabdian pada Masyarakat. Padang : Unand

[5] Soekarto, TS. 1985. Penilaian organoleptik untuk industri pangan dan hasil pertanian. Bharata. Jakarta.

[6] Tandjung, S.D. 2003. Ilmu Lingkungan. Yogyakarta: Laboratorium Ekologi, Fakultas Biologi,Universitas Gadjah Mada 